\title{
Root Reinforcement Effect on Cover Slopes of Solid Waste Landfill in Soil Bioengineering
}

\author{
Jeongjun Park ${ }^{1, * \mathbb{D}}$, Indae Kim ${ }^{2}$ and Jeong-Ku Kang ${ }^{3}$ \\ 1 Incheon Disaster Prevention Research Center, Incheon National University, Incheon 22012, Korea \\ 2 Geotechnical Engineering Department, Kyong-Ho Engineering \& Architects, Seoul 05702, Korea; \\ geokid@naver.com \\ 3 Research Institute, Korea Consultant, Incheon 21984, Korea; jeong99k@inu.ac.kr \\ * Correspondence: smearjun@hanmail.net
}

Citation: Park, J.; Kim, I.; Kang, J.-K Root Reinforcement Effect on Cover Slopes of Solid Waste Landfill in Soil Bioengineering. Sustainability 2021, 13, 3991. https://doi.org/10.3390/ su13073991

Academic Editor: Giuseppe Cardile

Received: 5 March 2021

Accepted: 1 April 2021

Published: 2 April 2021

Publisher's Note: MDPI stays neutral with regard to jurisdictional claims in published maps and institutional affiliations.

Copyright: (c) 2021 by the authors. Licensee MDPI, Basel, Switzerland. This article is an open access article distributed under the terms and conditions of the Creative Commons Attribution (CC BY) license (https:/ / creativecommons.org/licenses/by/ $4.0 /)$.

\begin{abstract}
This study investigated the effect of vegetation plant roots on the stability of the cover slopes of solid waste landfills. A large direct shear test and a root tensile strength test were conducted to quantify the effect of rooted soil of revegetation plants on the increment in shear strength of the soil as a method to protect the cover slope of solid waste landfills. In the large direct shear test, an increase in the shear strength of the ground with the presence of roots was observed, and the root reinforcement proposed in the literature was modified and proposed by analyzing the correlation between the root diameter and the tensile strength according to water content. The stability of the slope revegetation of a landfill facility, considering the root reinforcement effect of revegetation, was calculated by conducting a slope stability analysis reflecting the unsaturated seepage analysis of rainfall conditions for various analysis conditions, such as the gradient, the degree of compactness, the thickness of the cover, and the rooted soil depth of the landfill facility.
\end{abstract}

Keywords: solid waste landfill; slope revegetation; root reinforcement; rooted soil; slope stability

\section{Introduction}

The final covered layer of a solid waste landfill must satisfy various requirements such as preventing the inflow of rainfall, preventing the generation of toxic gases and odors, and supporting plant growth. However, because the final covered slope is prone to collapse due to its shallow soil thickness, related regulations such as embankment slope, compaction criteria, and stability analysis methods are insufficient, and accidents of slope collapse frequently occur. Therefore, slope protection afforded by vegetation prevents the direct inflow of rainfall on the slope's surface, thus securing stability against surface layer loss and scouring, owing to an increase in shear strength provided by plant roots. This also creates a visual sense of harmony with surrounding vegetation [1].

As such, soil bioengineering stabilizes slopes, limiting their impact on ecosystems and is a technique increasingly used worldwide. However, its effectiveness requires better assessment through post-intervention environmental monitoring [1-4]. Here, root reinforcement is a mechanism through which forests contribute to the prevention and mitigation of shallow soil instabilities-one of the main hazards in mountain areas $[5,6]$. It is well recognized that roots reinforce soil and that the distribution of roots within vegetated slopes strongly influences the spatial distribution of soil strength [7]. When a driving force occurs on a slope where the roots of the plants are located, the roots at the shear plane exert a tensile force to increase the shear resistance of the ground [8-11].

In particular, revegetation plants in solid waste landfills offer important protection to the final cover system. Tree roots can go very deep and invade the drainage layer as well as the impermeable layer. Therefore, the seeds of herbaceous plants and pasture species are planted on the cover slope of solid waste landfills. However, although these plants can quickly provide ground cover, they are often culled within two or three years, and 
therefore a combination of native herbaceous plants and pasture species has an advantage for mixed vegetation $[2,4,12,13]$.

In addition, in the stability analysis of the cover slope of a solid waste landfill, rainfall conditions should be reviewed under the most vulnerable conditions. In the design of existing case studies, rainfall conditions were either saturated to the surface, or a stability analysis was conducted that only considered the rise in groundwater level. However, if seepage occurs in the ground because of actual rainfall, the wetting zone is deeper and groundwater levels rise. Most slope failure occurs in the unsaturated zone in the upper part of the level of groundwater. Therefore, a reliable stability analysis should consider rainfall conditions, coupled with a seepage analysis, that reflects the unsaturated characteristics of the ground; a slope stability analysis in connection with this is a reasonable simulation of the actual ground behavior [14-16].

In this paper, a large direct shear test and a root tensile strength test are conducted to investigate the root reinforcement effect due to the root cohesion on the covered soil slope. In addition, unsaturated seepage analysis is performed considering the maximum rainfall intensity and rainfall duration, and the seepage-stability coupling analysis is performed to present the stability conditions for the cover slope of a solid waste landfill.

\section{Root Reinforcement Theory of Revegetation Slopes}

It is very difficult to quantitatively evaluate slope reinforcement effect via the roots of revegetation plants, because it appears differently depending on the type of vegetation, climate, and ground conditions [17-22]. Ground reinforced with roots generates additional cohesion $\left(c_{r}\right)$ because of both the roots and the inherent effective cohesion of the soil $\left(c^{\prime}\right)$ when the slope is destroyed [23-25]. The ground reinforcement effect by the roots can be calculated as the sum of the cohesive forces using the Mohr-Coulomb equation shown in Equation (1)

$$
\tau_{\mathrm{f}}=c^{\prime}+\left(\sigma_{n}-\mathrm{u}\right) \tan \varphi^{\prime}+c_{\mathrm{r}}
$$

where $\tau_{\mathrm{f}}$ is the shear strength, $c^{\prime}$ is the effective cohesive force, $\sigma_{n}$ is the total vertical stress, $\mathrm{u}$ is the pore water pressure, $\varphi^{\prime}$ is the internal friction angle, and $c_{r}$ is the root cohesion.

The representative models for calculating $c_{r}$, which is the effect of the root strength reinforcement, are Wu and Waldron's model (WWM) $[23,24,26]$ and the fiber bundle model (FBM) [17]. Both models include root density, root tensile strength $\left(\mathrm{T}_{\mathrm{r}}\right)$, and root direction function across the shear plane.

The main difference between the two models is that the WWM assumes that all roots are damaged at the same time during the shear failure of a slope, whereas the FBM determines the order of root destruction step by step, under the assumption that the roots are gradually damaged [27].

In this study, WWM, the most well-known model, was used to show the ground reinforcement effect of plant roots. $\mathrm{Wu}$ [23] presented a model to predict the increase in shear strength of the ground caused by roots. This model makes the following assumptions: The roots are perpendicular to the shear plane of the soil; the roots are fixed to a sufficient length, so that they do not escape from the shear zone; and the tensile strength of the roots is fully expressed during shearing. The root cohesion predicted by this model can be shown as Equation (2)

$$
c_{r}=T_{r}\left(A_{r} / A\right)(\cos \theta \tan \varphi+\sin \theta)
$$

where $c_{r}$ is the root cohesion, $T_{r}$ is the average tensile strength of the roots, $A_{r} / A$ is the root area ratio (RAR), $\varphi$ is the internal friction angle of the soil, $\theta$ is the shear twist angle $\left(=\tan ^{-1}(x / z)\right), x$ is the deformation distance of the roots, and $z$ is the shear area. Equation (2) shows that an increase in shear strength is affected by the tensile force and area ratio of the root, the shear twist angle, and the internal friction angle of the soil.

Gray and Leiser [25] consider that the shear twist angle $(\theta)$, measured through field tests and laboratory experiments, is usually between $40^{\circ}$ and $70^{\circ}$. When the internal friction angle $(\varphi)$ of the soil in Equation (2) ranges from $25^{\circ}$ to $40^{\circ}$ and the shear twist 
angle $(\theta)$ ranges from $40^{\circ}$ to $90^{\circ}, \cos \theta \tan \varphi+\sin \theta$ ranges from 1.0 to 1.3 , and thus it is relatively insensitive to changes in the shear twist angle $(\theta)$ and the internal friction angle ( $\theta$ ). Accordingly, Wu et al. [26] proposed Equation (2) as Equation (3) by applying the average value of 1.15 .

$$
\mathrm{c}_{\mathrm{r}}=1.15 \mathrm{~T}_{\mathrm{r}}\left(\mathrm{A}_{\mathrm{r}} / \mathrm{A}\right)
$$

The model of [26] was analyzed on the assumption that the roots penetrated the ground in a direction perpendicular to the shear plane. However, since actual roots are distributed randomly, a root strength reinforcement model inclined to the shear plane can be considered. We can see that when the initial gradient (i) of the root is more than $90^{\circ}$, it receives more compressive force than tensile force. Gray and Leiser [25] expressed the root cohesion $\left(c_{r}\right)$ of this model as Equation (4)

$$
c_{r}=T_{r}\left(A_{r} / A\right)[\sin (90-\theta)+\cos (90-\theta) \tan \varphi]
$$

where $\theta$ is $\tan ^{-1}\left(1 / m+(\operatorname{tani})^{-1}\right), m$ is $x / z$, and $i$ is the initial gradient of the root.

According to the deformation ratio by the tensile force $(\mathrm{m}=\mathrm{x} / \mathrm{z})$, when the initial gradient of the root ranges from $30^{\circ}$ to $60^{\circ}$, the value of $\sin (90-\theta)+\cos (90-\theta) \tan \varphi$ is the same as the range applied in Equation (3). For these two types of models, Gray and Ohashi [28] conducted shear tests on fibers perpendicular to the shear plane, as well as fibers that are randomly distributed, and subsequently suggested a root strength reinforcement model that was perpendicular to the shear plane.

As a result, $c_{r}$, the increase in shear strength at the failure surface because of the root, can be expressed as Equation (5) by simplifying it as the root-soil interaction coefficient [29], taking into account the average tensile strength of the root, the root area ratio, and the direction and failure process of the root:

$$
c_{r}=k \mathrm{~T}_{\mathrm{r}}\left(\mathrm{A}_{\mathrm{r}} / \mathrm{A}\right)
$$

As the $k$ value in Equation (5), Wu et al. [26] assumed 1.15, as in Equation (3), but when the slope is actually destroyed, the tensile strength of all roots is not mobilized at the same time, and thus using the entire tensile strength of the roots as a resistance value may lead to overestimation.

Liang et al. [30] presented a $k$ value of 0.312 to 0.318 for trees such as willow and bushes, and 1.07 as a $k$ value for herbaceous plants such as turf grass, acquired by means of a direct shear test. According to a number of laboratory experiments and field studies, $k$ ranges from 0.25 to 1.15 (e.g., [8,17,18,31-35]). In South Korea, under the assumption that the tensile stress of the root at shear failure is 40 to $50 \%$ of the total tensile strength, Lee et al. [36] modified the $k$ value from 1.15 to 0.6, and proposed it as Equation (6):

$$
c_{r}=0.6 T_{r}\left(A_{r} / A\right)
$$

According to Equations (2)-(6), an increase in shear strength of the ground because of the root depends on the average tensile strength and the root area ratio. Several researchers have suggested that the average tensile strength has a correlation with the root diameter at the shear plane, which is generally expressed in the form of Equation (7) [37]

$$
\mathrm{T}_{\mathrm{r}}=\alpha \mathrm{D}^{\beta}
$$

where $\mathrm{D}$ is the diameter of the root, with $\alpha$ and $\beta$ representing empirical coefficients, found experimentally, that differ depending on the characteristics of the sample. In particular, $\beta$ is lower than 0 , which indicates that as the root diameter increases, the tensile strength decreases. In addition, it is difficult to accurately measure the root area ratio on the failure surface. In an experiment that measured the tensile strength and root area ratio for each type of root, Gray and Leiser [25] reported that root area ratio was proportional to the tensile strength within the range of 0.05 to $0.15 \%$. Many researchers have expressed the tensile 
strength of plant roots as correlating with the root diameter, as shown in Equation (7). Mao et al. [34] presented correlation coefficients between the root diameter and tensile strength by species, obtained by means of a statistical analysis based on 81 field and laboratory tests studied in various regions of the world.

\section{Materials and Methods}

In this study, a large direct shear test and a root tensile strength test were conducted to quantify the effect of the rooted soil of revegetation plants on the increment in shear strength of the soil. Three sets of undisturbed block samples were collected considering the distribution of the roots and the specifications of the tester $(300 \mathrm{~mm}$ length, $300 \mathrm{~mm}$ width, and $200 \mathrm{~mm}$ height).

The shear test was performed on non-vegetated soils under the same conditions, such as the block sample containing roots in a large direct shear test, using the result of a field unit weight test in order to analyze the change in shear strength of the ground with roots present. Additionally, twelve tensile strength tests were conducted according to the diameter and the water content of the root. Root cohesion was calculated by means of a correlation analysis between the results of the large direct shear test and the root tensile strength test, while the effect of increasing the shear strength of the ground with vegetation roots was derived by comparing the results to those presented by existing researchers.

\subsection{Shear Strength Test and Tensile Strength Test}

\subsubsection{Geotechnical Characteristics of the Test Samples}

Field unit weight tests, particle size distribution tests, natural water content tests, and Atterberg limit tests were conducted to identify the geotechnical physical properties of the soil with roots. Table 1 lists the results of analyzing the geotechnical physical properties of the soil samples, which were categorized as well-graded sand with clay (SW-SC) under the unified soil classification system (USCS).

Table 1. Soil characteristics of the field sites.

\begin{tabular}{cccccc}
\hline $\begin{array}{c}\text { Geotechnical } \\
\text { Physical } \\
\text { Properties }\end{array}$ & $\begin{array}{c}\text { Wet Unit Weight, } \\
\gamma_{\mathbf{t}}\left(\mathbf{k N / \mathbf { m } ^ { 3 } )}\right.\end{array}$ & $\begin{array}{c}\text { Water Content, w } \\
\mathbf{( \% )}\end{array}$ & $\begin{array}{c}\text { Liquid Limit, LL } \\
\mathbf{( \% )}\end{array}$ & $\begin{array}{c}\text { Plastic Limit, PL } \\
\mathbf{( \% )}\end{array}$ & $\begin{array}{c}\text { Unified Soil } \\
\text { System, USCS }\end{array}$ \\
\hline Values & 12.8 & 9.4 & 46.6 & 37.0 & Well-graded sand \\
with clay (SW-SC)
\end{tabular}

As a test material for analyzing the effect of increasing the strength of the rooted soil of revegetation plants, shrubs were selected that were easy to sample, and the strength of the roots was measured. Shrubs are small plants and have several stems from the bottom. The representative species of shrubs are Forsythia koreana, Rhododendron mucronulatum, and Indigofera pseudotinctoria; out of them, the Indigofera pseudotinctoria used in this test was about 2-2.5 $\mathrm{m}$ in height; it is distributed in South Korea, China, and Japan and is used to protect cut slopes or riverbanks.

\subsubsection{Test Methods}

The large direct shear test was conducted according to the test method of ASTM D 5321. Figure 1 shows the test equipment consisting of a shear box of $300 \mathrm{~mm} \times 300 \mathrm{~mm} \times 200 \mathrm{~mm}$, divided into upper and lower parts, a pressurizing device capable of controlling vertical load, a load cell capable of measuring shear force, a measuring device for horizontal and vertical displacement, and a shear rate controller. The load cell could be loaded up to a maximum shear force of $30 \mathrm{kN}$, and this tester loads the vertical load as an equally distributed load using an air compressor. In order to minimize the effect of the upper load on the shear strength, the upper box was fixed, and the lower shear box was moved to measure the shear force. Additionally, measurement data of the shear force and vertical 
and horizontal displacement were collected by a data logger and could be checked during the test in real time by means of a computer program.

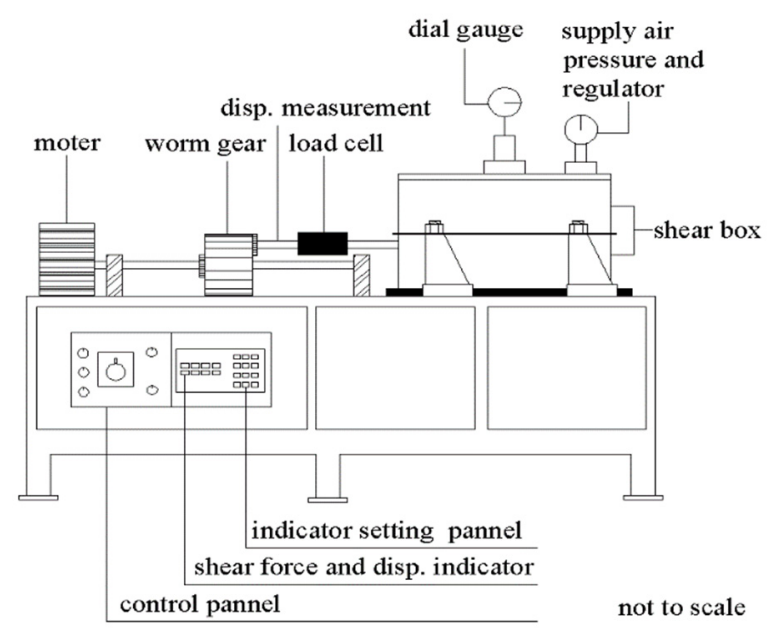

Figure 1. Schematic of the large direct shear test apparatus.

The large direct shear test was performed on two undisturbed block samples (vertical stress: $100.0 \mathrm{kPa}$ ) and soil samples (vertical stress: 20, 50, and $100 \mathrm{kPa}$ ) with the same water content and unit weight. In the test, grease was applied to the upper and lower contacts of the shear box to reduce frictional resistance, and the shear box was installed in the shear tester. For a block sample containing roots, the disturbance was minimized and placed in a shear box; for a soil sample, the testing soil was formed to the same unit weight as the sample containing roots by means of compaction. Then, the upper loading device and measuring device were set. The test was conducted by a deformation rate control method, in which shear stress was applied horizontally while a vertical load was applied, and the horizontal displacement was kept constant at a speed of $10 \mathrm{~mm} / \mathrm{min}$. The test was carried out until the horizontal displacement was at least $15 \%$.

For soil samples without roots, the shear stress was calculated by dividing the shear resistance according to the change in vertical load by the cross-sectional area. Then, the cohesion and the internal friction angle were found using Mohr-Coulomb failure envelopes. Afterwards, the change in strength of the ground with the presence of roots was analyzed by comparing the test results of the block sample containing roots.

The samples used in the root tensile strength test were carefully collected in order to avoid damaging them as much as possible, selecting them according to diameter to prepare the samples under three conditions of water content: Dry condition, wet condition, and natural condition.

Four samples for each condition were selected: Dry, wet, i.e., immersed in water at $20 \pm 2{ }^{\circ} \mathrm{C}$ for $72 \mathrm{~h}$; and the natural conditions of the site, before being weighed. After being dried with a dryer at $103 \pm 2{ }^{\circ} \mathrm{C}$ for $24 \mathrm{~h}$, a specimen was put in a desiccator to give it a constant weight, and the mass was measured to calculate the water content. Here, the constant weight was determined by measuring the mass at intervals of at least $8 \mathrm{~h}$; the mass change rate was $0.2 \%$ or less. Furthermore, in order to minimize the change in water content, the specimens were kept in a thermo-hygrostat $\left(15 \pm 1^{\circ} \mathrm{C}\right.$, humidity $\left.30 \pm 2 \%\right)$ for $24 \mathrm{~h}$.

Accurate measurement of the tensile strength of the roots proved difficult, owing to the strength of the root bark having been removed. Therefore, considering that the surface of the sample in the dry condition had been dried, a grip was formed using epoxy, and samples of the natural and wet conditions were taped to reinforce the connection before the tensile test was performed [10]. In order to minimize the measurement error of the fracture surface diameter of the root during the tensile strength test, Figure 2 shows that the diameter was measured precisely with an image analyzer. This is a stereo microscope that 
can accurately measure the length of an object by analyzing an image through a camera. When measuring the thickness of irregular roots in the root tensile strength test, the error was minimized and applied to obtain the cross-sectional area $[30,38]$.

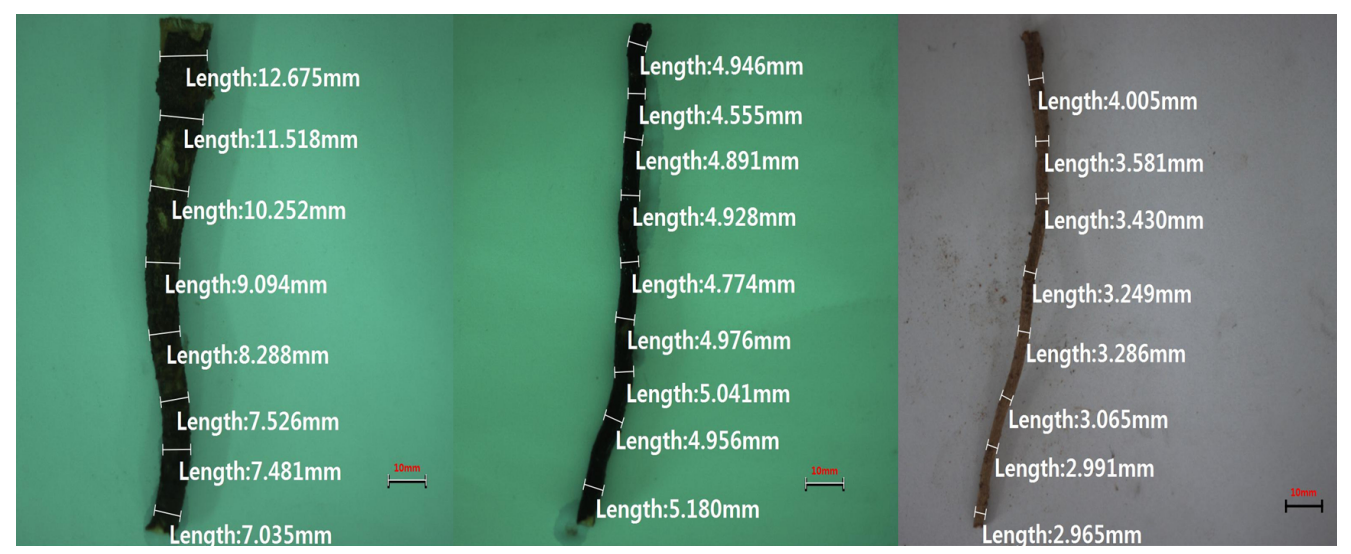

Figure 2. Vegetation root thickness measurement result.

\subsection{Stability Analysis Method of Cover Slopes}

\subsubsection{Analysis Condition}

As a condition of the analysis, in order to analyze the effect of the vegetation method on the stability of the final cover slope of the landfill, values of (1:1.5, 1:1.8, and 1:3.0) were assumed, considering the gradient of the standard slope as seen in a fill slope of the Ministry of Land, Infrastructure, and Transport in Korea. The thickness of the cover slope was taken as $(15,30,45$, and 60$) \mathrm{cm}$ by considering the minimum thickness $(60 \mathrm{~cm})$ of the vegetation zone according to the Waste Disposal Law and the growing depth of the plants. Additionally, in order to consider the ground reinforcement effect provided by the vegetation roots on the cover slope of the landfill facility, the minimum survival depths of turf, grass, and shrubs of 15 and $30 \mathrm{~cm}$ were applied as the root reinforcement depths.

Most stability analyses of cover slopes of landfills assume that the groundwater level is saturated to the ground surface during rainfall, and the strength constant of sandy soils is applied, which is densely compacted. However, most of the failures of a slope occur in the unsaturated section, and because of the thin soil layer on the slope, we would not to see expect a compacting effect on the cover slope. Thus, in this study, a seepage-stability coupled analysis was performed to reflect the characteristics of unsaturated soil during concentrated rainfall, and a stability analysis was conducted considering the non-compact condition by referring to the unit, weight, and strength constant of the block samples calculated by means of the field and laboratory tests. Figure 3 lists the analysis conditions and restrictions.

The ground parameters applied to the numerical analysis were assumed to be the strength constant in the compact/non-compact state by reflecting the literature data and test results, as shown in Table 2. For the strength parameter of the vegetation root reinforcement ground, the shear strength test results presented in the previous section were used.

Table 2. Geotechnical characteristics of soil for the stability analysis of covered slopes.

\begin{tabular}{ccccc}
\hline \multirow{2}{*}{ Type } & $\begin{array}{c}\text { Wet Unit Weight } \gamma_{\mathbf{t}} \\
\left(\mathbf{k N} / \mathbf{m}^{\mathbf{3}}\right)\end{array}$ & \multicolumn{2}{c}{ Cohesion c (kPa) } & \multicolumn{2}{c}{$\begin{array}{c}\text { Angle of Internal } \\
\text { Friction } \boldsymbol{\varphi}\left({ }^{\circ}\right)\end{array}$} \\
\cline { 3 - 5 } & 19 & c-Bare Soil & $\mathbf{c}^{\prime}+\mathbf{c}_{\mathbf{r}}$-Rooted Soil & 31 \\
\hline Compacted soil & 13 & 5 & 23 & 28 \\
\hline
\end{tabular}




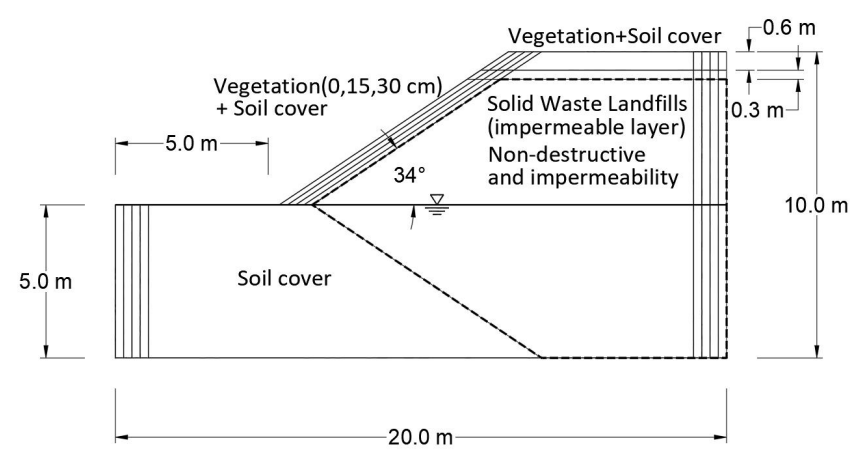

(a)

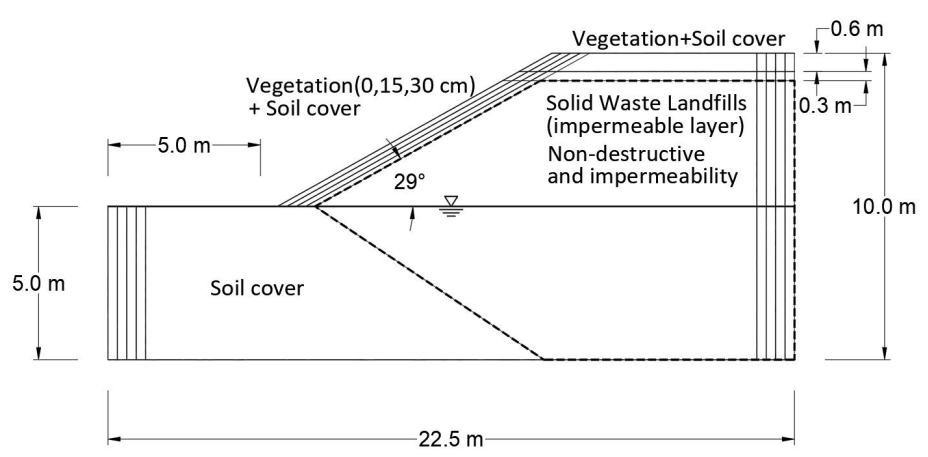

(b)

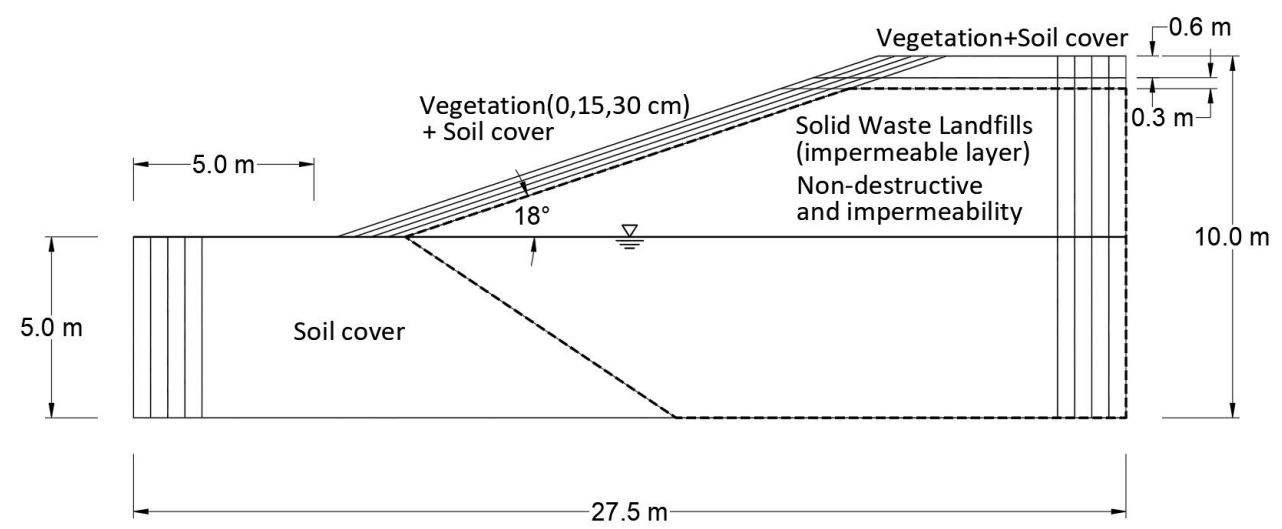

(c)

Figure 3. Schematic of the stability analysis of solid waste landfills: (a) Slope 1:1.5; (b) Slope 1:1.8; (c) Slope 1:3.0.

\subsubsection{Seepage-Stability Analysis Method in Unsaturated Slope}

In this paper, the water content characteristic curve for the stability analysis of the unsaturated slope was assumed to take the characteristic values of the unsaturated soil when compact or non-compact, using the results of the study [39] on sand and weathered granite soil in Incheon, South Korea. In that case, the equation [40] with a high correlation was applied to the water content characteristic curve, defined as the relationship between the amount of water in the soil and the matrix suction. For weathered granite soil, the parameters were $\mathrm{a}=40.91631 \mathrm{kPa}, \mathrm{n}=1.051779$, and $\mathrm{m}=0.7263589$; the air entry value was $13.74 \mathrm{kPa}$, and the residual volumetric water content was evaluated as $10.20 \%$, while for sandy soil, the parameters were $\mathrm{a}=5.572556 \mathrm{kPa}, \mathrm{n}=4.651409$, and $\mathrm{m}=0.5940426$; the air entry value was $4.05 \mathrm{kPa}$, and the residual volumetric water content was suggested as $6.80 \%$. 
In this study, GeoStudio's SEEP/w and SLOPE/w numerical analysis programs (GEOSLOPE International, Ltd.) were used, which were able to couple the unsaturated seepage analysis of rainfall conditions and the stability analysis of slopes. For the seepage analysis, after the water content characteristic curve, the unsaturated hydraulic conductivity, meteorological data to be analyzed on rainfall in the area were input, and the unsteady flow was analyzed, reflecting the rainfall duration for a total of 30 days from the time when the maximum rainfall occurred in the last 50 years. This allowed analysis of the formation of the unsaturated zone caused by seepage into the ground during rainfall and the change in pore water pressure caused by the rise in the groundwater level, in conjunction with the stability analysis considering the shear strength of the unsaturated soil.

The stability analysis of the slope calculated the safety factor for the force or moment equilibrium at the predicted failure surface, and from the most commonly used slice methods among the limit equilibrium methods, Bishop's method was used, which considers the static equilibrium against the applied load of the failed soil. The failure behavior of the slope was not a general circle-shaped failure, but was applied as a composite failure type of the circle and linear combination, in consideration of the interfacial failure between the linear materials of cover slopes in landfills and cover materials. The safety factor of the analysis slope was selected as the minimum safety factor within the rainfall duration.

\section{Results and Discussion}

\subsection{Root Reinforcement of Large Direct Shear Test}

Figure 4 shows the results of the large direct shear test. The increase in the cohesion of the ground that resulted from the reinforcement effect of the vegetation roots for the Root-01 sample was $30.92 \mathrm{kPa}$, and for the Root-02 sample, it was $36.00 \mathrm{kPa}$. This increase resulted from the tensile strength of the roots located on the shear failure plane and the area occupied by the roots. The average of the increase $\left(c_{r}\right)$ in shear strength by the roots calculated by means of the large direct shear test was $33.46 \mathrm{kPa}$. Afterwards, the root cohesion calculated by the average tensile strength of the roots and the root area ratio at the shear plane were compared.

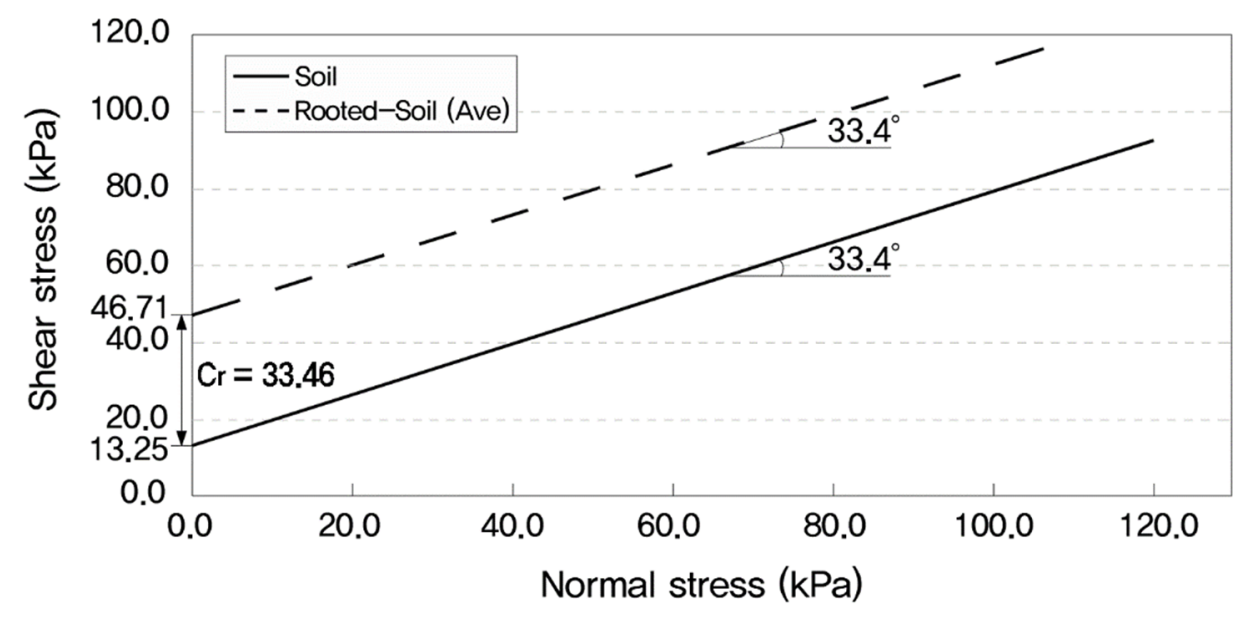

Figure 4. Additional cohesion of rooted soil using the Mohr-Coulomb failure envelope.

The effect of increasing strength of the ground by means of the roots is correlated with the area occupied by the roots in the failure plane. When the distribution area of the root is large in the failure plane, the ground reinforcement effect that results from the root cohesion is greater than when it is not. Thus, in this study, after completing a large direct shear test, the sample was excavated to the failure plane of the shear box to determine the distribution of the roots from the failure plane, and the quantity was measured according to the root diameter. Table 3 lists the area ratio of the roots based on the calculation of the root size on the shear plane after the large direct shear test. 
Table 3. The measured number of root diameters in the shear plane.

\begin{tabular}{|c|c|c|c|c|c|c|}
\hline \multirow[b]{2}{*}{ No. } & \multicolumn{5}{|c|}{ Number of Root Diameters } & \multirow[b]{2}{*}{ RAR * (\%) } \\
\hline & $\begin{array}{c}(0.0-2.0) \\
\mathrm{mm}\end{array}$ & $\begin{array}{c}(2.0-4.0) \\
\mathrm{mm}\end{array}$ & $\begin{array}{c}(4.0-6.0) \\
\mathrm{mm}\end{array}$ & $\begin{array}{c}(6.0-8.0) \\
\mathrm{mm}\end{array}$ & $\begin{array}{c}(8.0-12.0) \\
\mathrm{mm}\end{array}$ & \\
\hline Root-01 & 2 & 15 & 2 & 4 & 2 & 48 \\
\hline Root-02 & 11 & 4 & 4 & 4 & 1 & 39 \\
\hline
\end{tabular}

\subsection{Root Reinforecment of Tensile Strength Test}

Table 4 lists the measurement results of the water content of the samples according to the moisture condition. The water content of the sample in the dry condition was 16 to $18 \%$, which is a small deviation caused by the evaporation of water at a constant temperature, whereas that of the sample in the wet condition was 50 to $155 \%$, which are large values, because of the difference in the degree of absorption of moisture to the inside according to the thickness of the root. Furthermore, the water content of the samples in the natural condition ranged from 44 to $97 \%$, and the samples collected from the lower part of the root had a higher water content than those collected from the upper part did.

Table 4. Water content of vegetation roots.

\begin{tabular}{ccccccc}
\hline \multirow{2}{*}{$\begin{array}{c}\text { Moisture } \\
\text { Condition }\end{array}$} & Unit & \multicolumn{5}{c}{ Water Content } \\
\cline { 3 - 7 } & & $\mathbf{X 1}$ & $\mathbf{X 2}$ & $\mathbf{X 3}$ & $\mathbf{X 4}$ & Average \\
\hline $\begin{array}{c}\text { Dry } \\
\text { condition } \\
\text { Wet }\end{array}$ & $\%$ & 16.7 & 18.6 & 16.4 & 17.8 & 17.4 \\
$\begin{array}{c}\text { condition } \\
\text { Natural } \\
\text { condition }\end{array}$ & & 49.6 & 80.3 & 99.6 & 154.7 & 96.0 \\
\hline
\end{tabular}

Figure 5 shows the tensile strength test results according to the water content of the samples. The tensile strength of the samples exposed to air for a period of time as well as in the dry condition ranged from 14.4 to $16.5 \mathrm{~N} / \mathrm{mm}^{2}$. The epidermis and core were observed to be fractured together, without a slip at the connection. Tensile strength of the samples in the wet condition ranged from 12.8 to $20.4 \mathrm{~N} / \mathrm{mm}^{2}$, and a slip occurred with the epidermis in some areas adjacent to the connection, however the shape of the fracture with the core was confirmed. The tensile strength of the sample collected in the natural condition ranged from 11.9 to $24.2 \mathrm{~N} / \mathrm{mm}^{2}$; a slip occurred in the epidermis, and the shape of the fracture along with the core was observed.

By applying the average tensile strength measured in the root tensile strength test to the root reinforcement cohesion, and the root area ratio calculated in the large direct shear test, the root cohesion correction factor, $k$, for soil-root interaction in Equation (5) was derived as 0.47 . Hence, the constant of 1.15 suggested by [26] under the assumption that the tensile strength of the roots was fully expressed during the shear stress of the soil, and the constant of 0.6 suggested by [36] under the assumption that the tensile stress of the root provided 40 to $50 \%$ of the total tensile strength during shear fracture of the soil, can overestimate the reinforcement effect of the root. Therefore, in this study, as shown in Equation (8), 0.47 is suggested as the correction factor $(k)$ of the root cohesion of herbaceous plants and shrubs applied as vegetation on the slope $[26,29,36]$.

$$
\mathrm{c}_{\mathrm{r}}=0.47 \mathrm{~T}_{\mathrm{r}}\left(\mathrm{A}_{\mathrm{r}} / \mathrm{A}\right)
$$

The increase in the shear strength of the ground by the roots is proportional to the area (RAR) occupied by the roots on the shear plane. However, the area of the roots differs greatly depending on the soil hardness, vegetation density, and regional and geological 
conditions, making it difficult to estimate accurately. In this study, the root area ratio was assumed to be $0.1 \%$, based on the results of the study by [25], which suggested that the root area ratio is proportional to the increase in the shear strength within the range of 0.05 to $0.15 \%$.

The above results, showing that the increase in cohesion of the ground by the roots in the vegetation ground was $8.0 \mathrm{kPa}$, were used as input data when performing the stability analysis of the cover slope in the solid waste landfill.

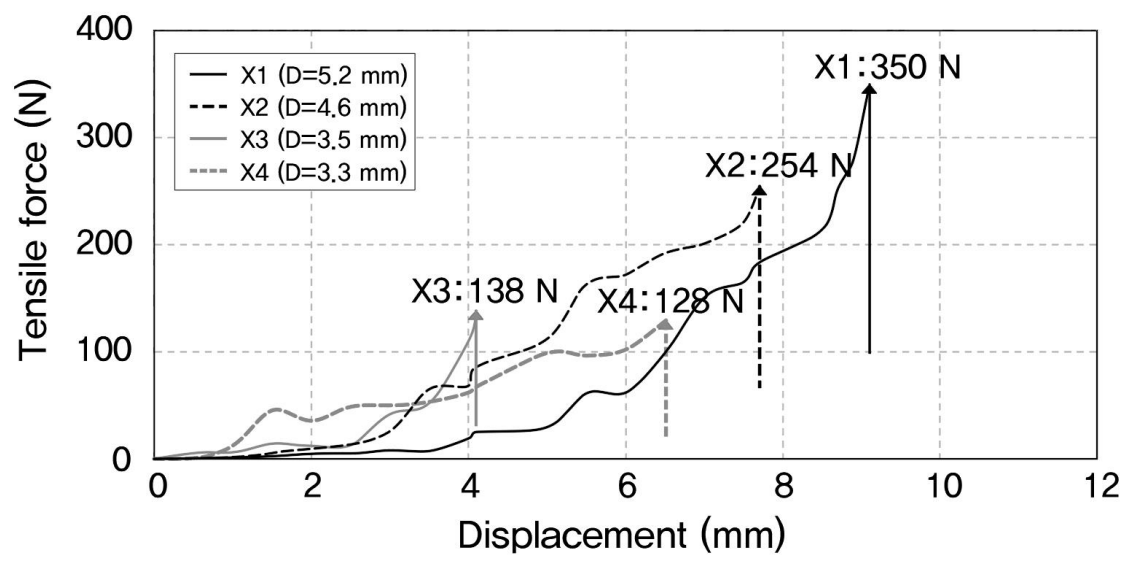

(a)

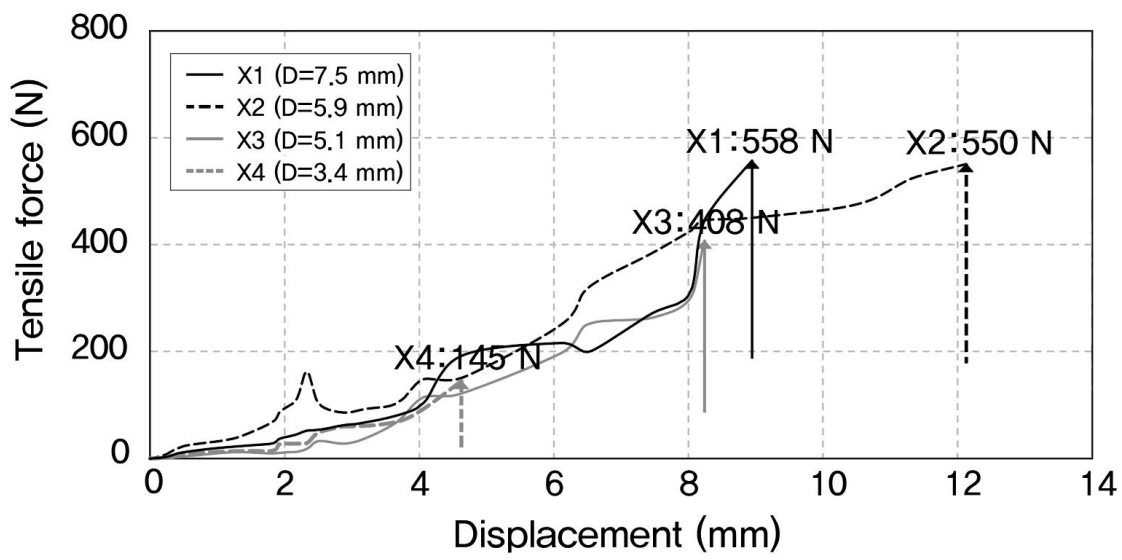

(b)

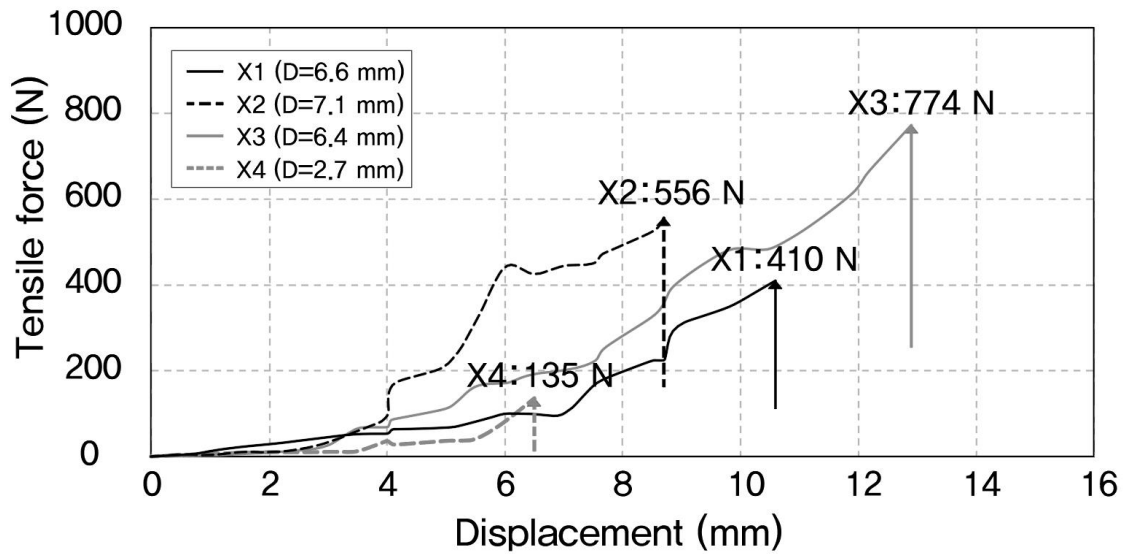

(c)

Figure 5. Tensile strength test results of vegetation roots: (a) Dry condition; (b) wet condition; (c) natural condition. 


\subsection{Stability Analysis of Cover Slopes}

In order to analyze the effect of vegetation roots on the stability of the cover slope of solid waste landfills, a numerical analysis was conducted using the limit equilibrium method. The numerical analysis considered the situation in which seepage into the ground occurs during rainfall, which is the most unstable condition when examining slope stability, and the reliability of the analysis result was ensured by means of a stability analysis reflecting the characteristics of the unsaturated soil.

For the seepage analysis of rainfall conditions, the seepage rate corrected for the rainfall intensity was applied, considering the change in the amount of seepage and run-off of rainwater according to the gradient of the slope, and the rainfall intensity and duration of rainfall in the Incheon area were used. By analyzing data from the Meteorological Administration, the maximum rainfall in the Incheon area since 1970 was found to be $302.5 \mathrm{~mm} /$ day on 27 July 1987. For the rainfall duration, an unsteady flow analysis was conducted for 1 month by applying 15 days before and after the time of occurrence of the maximum daily rainfall, in consideration of recent frequent localized torrential rain events.

The stability analysis of the cover slope of solid waste landfills was performed 66 times according to the gradient of the slope, the degree of compaction, the thickness of the cover, and root impact depth. Additionally, the minimum safety factor of the slope for each analysis condition was calculated.

Table 5 shows the results of the stability analysis of the slope according to the degree of compaction when vegetation is not planted. The compacted soil has a minimum safety factor of 198.4 to $212.8 \%$, which is roughly twice as much as that of the uncompacted soil. In addition, in both compacted and uncompacted conditions, as the thickness of the cover increased, the safety factor decreased, but the safety factor in the compacted condition showed a similar trend regardless of the gradient of the cover slope and the thickness of cover compared to the uncompacted condition.

Table 5. Results of slope stability analysis of the uncompacted and compacted states.

\begin{tabular}{|c|c|c|c|c|}
\hline Slope Angle & $\begin{array}{l}\text { Cover Slope } \\
\text { Thickness (cm) }\end{array}$ & $\begin{array}{l}\text { Safety Factor of the } \\
\text { Compacted State (FS) }\end{array}$ & $\begin{array}{c}\text { Safety Factor of the } \\
\text { Uncompacted State (FS) }\end{array}$ & $\begin{array}{c}\text { Change in the Safety Factor of } \\
\text { the Uncompacted State to } \\
\text { Compacted State }(\%)\end{array}$ \\
\hline \multirow{4}{*}{ 1:1.5 } & 15 & 12.012 & 5.817 & 206.5 \\
\hline & 30 & 6.678 & 3.219 & 207.4 \\
\hline & 45 & 4.816 & 2.339 & 205.9 \\
\hline & 60 & 3.871 & 1.881 & 205.8 \\
\hline \multirow{4}{*}{$1: 1.8$} & 15 & 13.356 & 6.506 & 205.3 \\
\hline & 30 & 7.462 & 3.612 & 206.6 \\
\hline & 45 & 5.378 & 2.609 & 206.1 \\
\hline & 60 & 4.331 & 2.098 & 206.4 \\
\hline \multirow{4}{*}{$1: 3.0$} & 15 & 20.033 & 9.415 & 212.8 \\
\hline & 30 & 10.715 & 5.401 & 198.4 \\
\hline & 45 & 7.747 & 3.758 & 206.2 \\
\hline & 60 & 6.243 & 3.018 & 206.8 \\
\hline
\end{tabular}

Figure 6 shows the results of the stability analysis for each cover thickness according to the compacted and non-compacted conditions of the cover slope. The correlation coefficient was higher than $86 \%$ at the slope under all conditions. As the thickness of the cover increases, the minimum safety factor tends to decrease in both compacted and non-compacted conditions, and when the gradient of the slope is steep, the safety factors of compacted and non-compacted conditions show a similar trend. However, when the gradient is 1:3.0, which is gradual, the minimum safety factor increases significantly in both the compacted and the non-compacted conditions. Overall, when the thickness of the cover is less than $30 \mathrm{~cm}$, the safety factor tends to increase significantly in both compacted and uncompacted conditions.

In this study, the stability analysis was conducted to analyze the reinforcement effect of the cover slope according to the root impact depth of the vegetation plants. The depth of 
the root reinforcement was applied by dividing it into 15 and $30 \mathrm{~cm}$, in consideration of the minimum soil depth for plant survival and growth on the slope.

When the root impact effect depth was $15 \mathrm{~cm}$, at the same gradient based on uncompacted soil cover without vegetation (Figure 7), the minimum safety factor increased from 106.4 to $255.8 \%$; when the root impact depth was $30 \mathrm{~cm}$ (Figure 8), the minimum safety factor increased from 133.3 to $252.0 \%$. The minimum increase in the safety factor occurred at $60 \mathrm{~cm}$ thickness of the uncompacted cover, while the maximum increase in the safety factor occurred at both $15 \mathrm{~cm}$ thickness of the uncompacted cover and $30 \mathrm{~cm}$ root impact depth. Figure 9 shows the results of the slope stability analysis considering the root reinforcement effect of vegetation plants according to the gradient of the slope, the thickness of cover, the degree of compactness, and the root impact depth.

The stability analysis of the cover slope considering the root impact depth showed that the tendency to increase the safety factor of the slope because of the reinforcement effect of the roots was evident, indicating that the vegetation method applied to the cover slope of the landfill was effective in increasing the stability of the slope.

\section{Factor of safety (FS)}

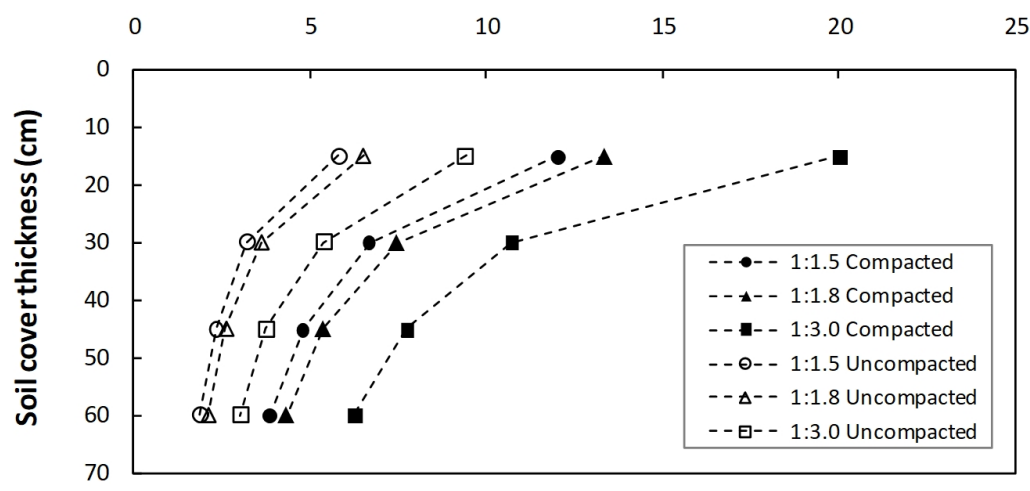

Figure 6. Slope stability analysis result for the uncompacted and compacted states.

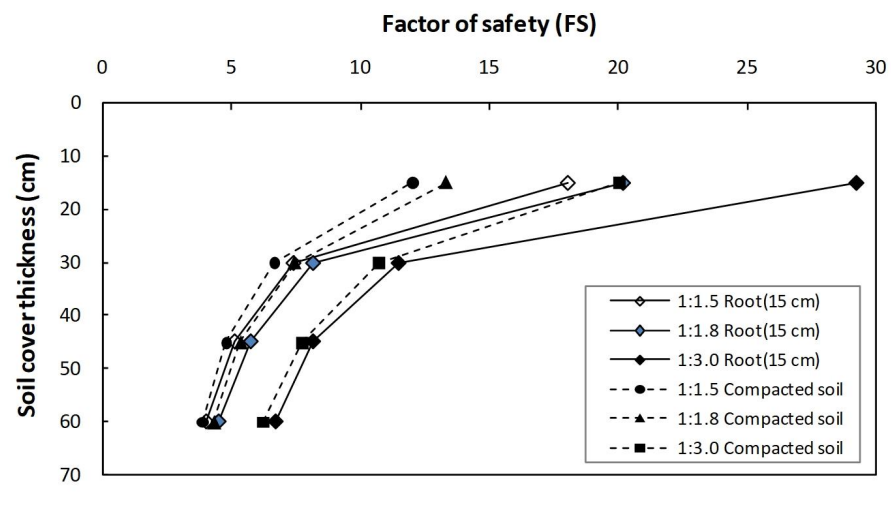

(a)

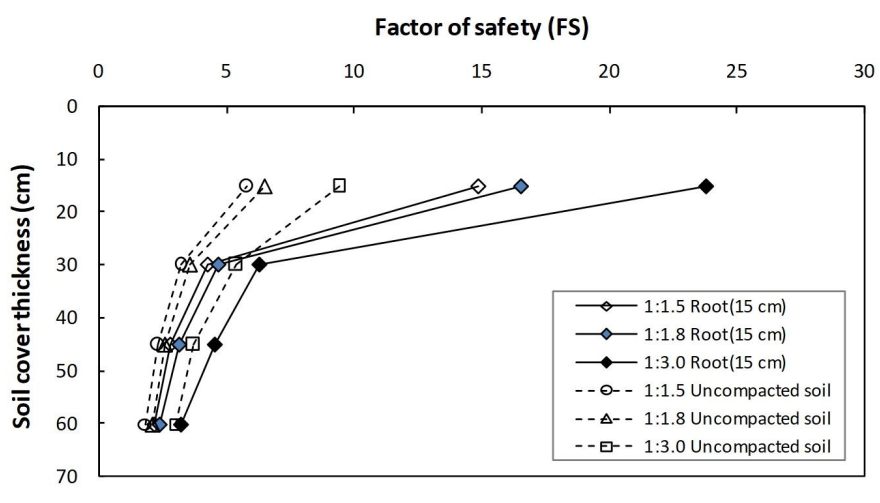

Figure 7. Slope stability analysis result according to the root reinforcement depth $(15 \mathrm{~cm})$ and cover thickness: (a) Compacted soil; (b) uncompacted soil. 

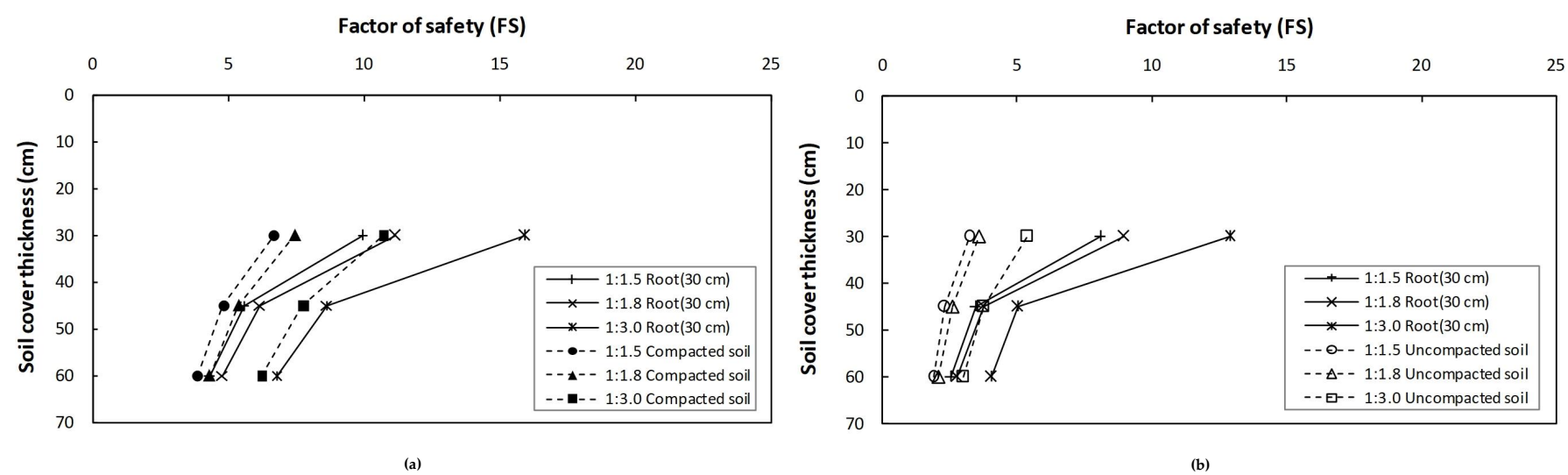

Figure 8. Slope stability analysis result according to the root reinforcement depth $(30 \mathrm{~cm})$ and cover thickness: (a) compacted soil; (b) uncompacted soil.

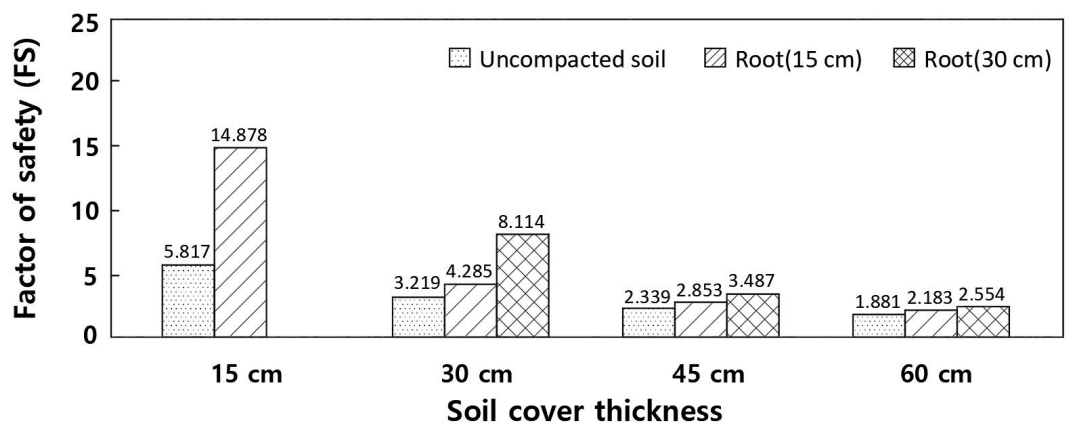

(a)

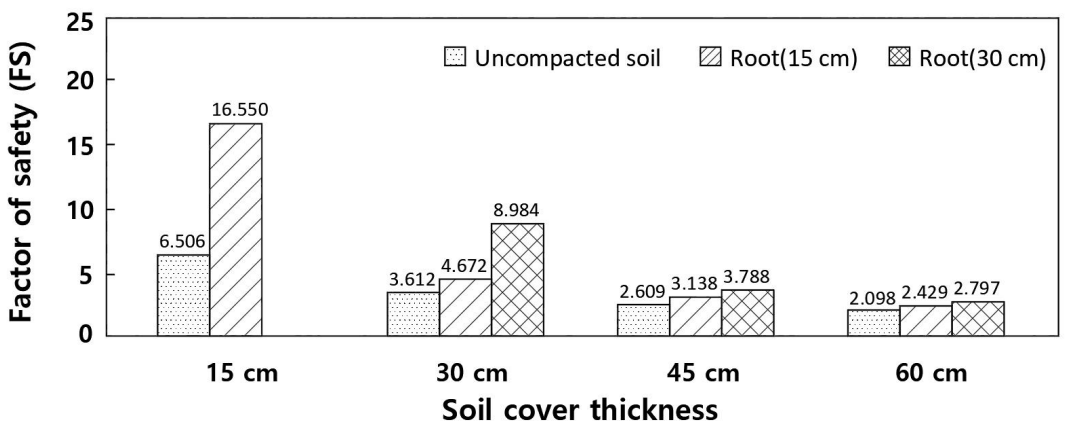

(b)

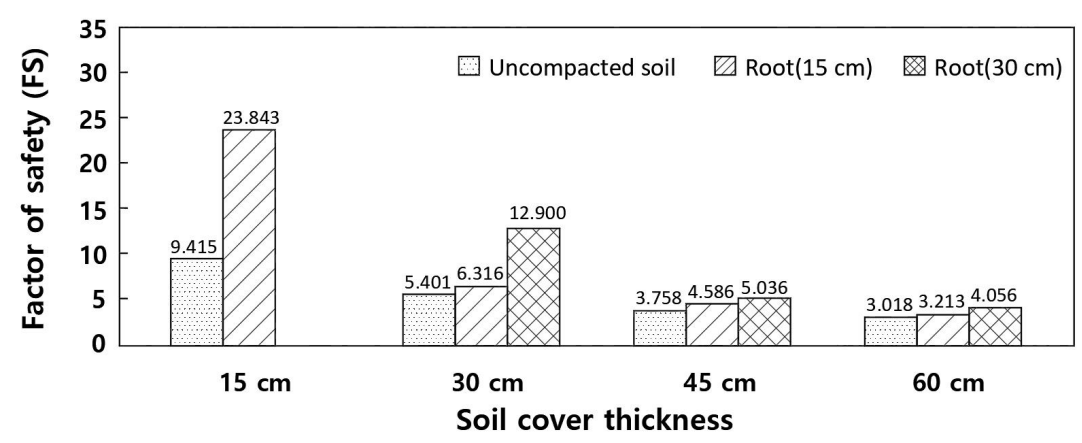

(c)

Figure 9. Slope stability analysis result considering the root reinforcement effect: (a) Slope 1:1.5; (b) Slope 1:1.8; (c) Slope 1:3.0. 


\section{Conclusions}

This study investigated the effect of vegetation plant roots on the stability of the cover slopes of solid waste landfills. To this end, a large direct shear test including roots and a root tensile strength test were conducted, which were correlated and analyzed to confirm the increase in tensile strength of the ground was because of the presence of roots. In this process, the correction factor for root cohesion was modified and proposed. The stability of the cover slope of a landfill facility, considering the reinforcement effect of vegetation roots, was calculated by conducting a slope stability analysis reflecting the unsaturated seepage analysis of rainfall conditions for various analysis conditions. This included the gradient, the degree of compactness, thickness of the cover, and the root impact depth of the landfill facility. The conclusions of this study are as follows:

1. A large direct shear test and a root tensile strength test were conducted to analyze the ground reinforcement effect provided by vegetation roots. The correlation between the root cohesion calculated in the direct shear test and the root tensile strength measured in the tensile strength test was analyzed, and the correction factor of 0.47 was proposed for the root cohesion of herbaceous plants or shrubs used in the slope vegetation method in South Korea.

2. The stability effect of vegetation roots on the cover slope of the solid waste landfills was analyzed by coupling the unsaturated seepage analysis of rainfall conditions, and the stability analysis of the slope. The increase in the shear strength of the ground caused by the roots was calculated using the root cohesion correction factor, and the root tensile strength test results. The impact depth of the vegetation root was applied at 15 to $30 \mathrm{~cm}$ in consideration of the characteristics of vegetation plants in landfills. As a result of the slope stability analysis, compared to the uncompacted condition without considering the root effect, the minimum safety rate increased from 106.5 to $255.8 \%$ for the cover slope considering the root reinforcement effect and compacted condition. Hence, vegetation roots and the degree of compactness have an important influence on the stability of the cover slope of a landfill facility.

3. For the vegetation plants planted on the cover slope of solid waste landfills, it is suitable to mix and install grasses, herbaceous plants, and small shrubs with a shallow depth of growth to protect the landfill facility lining system and maintain the vegetation; it is reasonable to apply 15 to $20 \mathrm{~cm}$ to the root impact depth of the vegetation plants, considering domestic and foreign research cases, the related standards, and the characteristics of the vegetation plants. Additionally, in order to secure the minimum thickness required for the maintenance of the final cover function and the growth of the vegetation plants, the results of the stability analysis of the slope in this study indicate that the cover thickness of the cover slope in solid waste landfills should be at least $30 \mathrm{~cm}$.

Author Contributions: Conceptualization, J.P.; methodology, J.P. and I.K.; software, J.P. and I.K.; validation, I.K. and J.-K.K.; formal analysis, J.P. and I.K.; investigation, I.K. and J.-K.K.; resources, I.K.; data curation, J.P.; writing-original draft preparation, J.P. and I.K.; writing-review and editing, J.P.; visualization, I.K. and J.-K.K.; supervision, J.P.; project administration, J.P. and J.-K.K. All authors have read and agreed to the published version of the manuscript.

Funding: This research received no external funding.

Institutional Review Board Statement: Not applicable.

Informed Consent Statement: Not applicable.

Data Availability Statement: The data presented in this study are available on request to the corresponding author. The data are not publicly available as they form part of an ongoing study.

Conflicts of Interest: The authors declare no conflict of interest. 


\section{References}

1. Bischetti, G.B.; Di Fi Dio, M.; Florineth, F. On the origin of soil bioengineering. Landsc. Res. 2014, 39, 583-595. [CrossRef]

2. Giupponi, L.; Borgonovo, G.; Giorgi, A.; Bischetti, G.B. How to renew soil bioengineering for slope stabilization: Some proposals. Landsc. Ecol. Eng. 2019, 15, 37-50. [CrossRef]

3. Rey, F.; Bifulco, C.; Bischetti, G.B.; Bourrier, F.; De Cesare, G.; Florineth, F.; Graf, F.; Marden, M.; Mickovski, S.B.; Phillips, C.; et al. Soil and water bioengineering: Practice and research needs for reconciling natural hazard control and ecological restoration. Sci. Total Environ. 2019, 648, 1210-1218. [CrossRef] [PubMed]

4. Stokes, A.; Douglas, G.B.; Fourcaud, T.; Giadrossich, F.; Gillies, C.; Hubble, T.; Kim, J.H.; Loades, K.W.; Mao, Z.; McIvor, I.R.; et al. Ecological mitigation of hillslope instability: Ten key issues facing researchers and practitioners. Plant Soil 2014, $377,1-23$. [CrossRef]

5. Cislaghi, A.; Alterio, E.; Fogliata, P.; Rizzi, A.; Lingua, E.; Vacchiano, G.; Bischetti, G.B.; Sitzia, T. Effects of tree spacing and thinning on root reinforcement in mountain forests of the European Southern Alps. For. Ecol. Manag. 2021, 482, 118873. [CrossRef]

6. Dias, A.S.; Pirone, M.; Urciuoli, G. Review on the Methods for Evaluation of Root Reinforcement in Shallow Landslides. In Proceedings of the 4th World Landslide Forum, Ljubljana, Slovenia, 29 May-2 June 2017; pp. 641-648.

7. Schwarz, M.; Rist, A.; Cohen, D.; Giadrossich, F.; Egorov, P.; Büttner, D.; Stolz, M.; Thormann, J.-J. Root reinforcement of soils under compression. J. Geophys. Res. Earth Surf. 2015, 120, 2103-2120. [CrossRef]

8. Comino, E.; Druetta, A. The effect of Poaceae roots on the shear strength of soils in the Italian alpine environment. Soil Tillage Res. 2010, 106, 194-201. [CrossRef]

9. Cislaghi, A.; Cohen, D.; Gasser, E.; Bischetti, G.B.; Schwarz, M. Field measurements of passive earth forces in steep, shallow, landslide-prone areas. J. Geophys. Res. Earth Surf. 2019, 124, 838-866. [CrossRef]

10. Giadrossich, F.; Schwarz, M.; Cohen, D.; Cislaghi, A.; Vergani, C.; Hubble, T.; Phillips, C.; Stokes, A. Methods to measure the mechanical behaviour of tree roots: A review. Ecol. Eng. 2017, 109, 256-271. [CrossRef]

11. Vergani, C.; Giadrossich, F.; Schwarz, M.; Buckley, P.; Conedera, M.; Pividori, M.; Salbitano, F.; Rauch, H.P.; Lovreglio, R. Root reinforcement dynamics of European coppice woodlands and their effect on shallow landslides: A review. Earth Sci. Rev. 2017, 167, 88-102. [CrossRef]

12. Gilardelli, F.; Vergani, C.; Gentili, R.; Bonis, A.; Chanteloup, P.; Citterio, S.; Chiaradia, E.A. Root Characteristics of Herbaceous Species for Topsoil Stabilization in Restoration Projects. Land Degrad. Dev. 2017, 28, 2074-2085. [CrossRef]

13. Giupponi, L.; Corti, C.; Manfredi, P. The vegetation of the Borgotrebbia landfill (Piacenza, Italy): Phytosociological and ecological characteristics. Plant Biosyst. An Int. J. Deal. Asp. Plant Biol. 2015, 149, 865-874. [CrossRef]

14. Ng, C.W.W.; Ni, J.J.; Leung, A.K.; Wang, Z.J. A new and simple water retention model for root-permeated soils. Geotech. Lett. 2016, 6, 106-111. [CrossRef]

15. Gallipoli, D.; Wheeler, S.J.; Karstunen, M. Modelling the variation of degree of saturation in a deformable unsaturated soil. Geotechnique 2003, 53, 105-112. [CrossRef]

16. Leung, A.K.; Garg, A.; Ng, C.W.W. Effects of plant roots on soil-water retention and induced suction in vegetated soil. Eng. Geol. 2015, 193, 183-197. [CrossRef]

17. Pollen, N.; Simon, A. Estimating the mechanical effects of riparian vegetation on stream bank stability using a fiber bundle model. Water Resour. Res. 2005, 41, W07025. [CrossRef]

18. Schwarz, M.; Lehmann, P.; Or, D. Quantifying lateral root reinforcement in steep slopes-from a bundle of roots to tree stands. Earth Surf. Process. Landf. 2010, 35, 354-367. [CrossRef]

19. Zhang, C.B.; Chen, L.H.; Liu, Y.P.; Ji, X.D.; Liu, X.P. Triaxial compression test of soil-root composites to evaluate influence of roots on soil shear strength. Ecol. Eng. 2010, 36, 19-26. [CrossRef]

20. Foresta, V.; Capobianco, V.; Cascini, L. Influence of grass roots on shear strength of pyroclastic soils. Can. Geotech. J. 2020, 57, 1320-1334. [CrossRef]

21. Cazzuffi, D.; Corneo, A.; Crippa, E. Slope stabilisation by perennial "gramineae" in southern Italy: Plant growth and temporal performance. Geotech. Geol. Eng. 2006, 24, 429-447. [CrossRef]

22. Graf, F.; Frei, M.; Böll, A. Effects of vegetation on the angle of internal friction of a moraine. For. Snow Landsc. Res. 2009, 82, 61-77.

23. $\mathrm{Wu}, \mathrm{T} . \mathrm{H}$. Investigation of Landslides on Prince of Wales Island, Geotechnical Engineering Report 5; Civil Engineering Department, Ohio State University: Columbus, OH, USA, 1976.

24. Waldron, L.J. The shear resistance of root permeated homogeneous and stratified soil. Soil Sci. Soc. Am. J. 1977, 132, 843-849. [CrossRef]

25. Gray, D.H.; Leiser, A.J. Biotechnical Slope Protection and Erosion Control; Van Nostrand Reinhold: New York, NY, USA, 1982.

26. Wu, T.H.; McKinnell, P.; Swanston, D.N. Strength of tree roots and landslides on Prince of Wales Island, Alaska. Can. Geotech. J. 1979, 16, 19-23. [CrossRef]

27. Thomas, R.E.; Pollen-Bankhead, N. Modeling root-reinforcement with a fiber-bundle model and Monte Carlo simulation. Ecol. Eng. 2010, 36, 47-61. [CrossRef]

28. Gray, D.H.; Ohashi, H. Mechanics of fiber reinforcements in sand. J. Geotech. Eng. Div. 1983, 109, 335-353. [CrossRef]

29. Meijer, G.J.; Bengough, A.G.; Knappett, J.A.; Loades, K.W.; Nicoll, B.C. New in situ techniques for measuring the properties of root-reinforced soil laboratory evaluation. Geotechnique 2016, 66, 27-40. [CrossRef] 
30. Liang, T.; Bengough, A.G.; Knappett, J.A.; MuirWood, D.; Loades, K.W.; Hallett, P.D.; Boldrin, D.; Leung, A.K.; Meijer, G.J. Scaling of the reinforcement of soil slopes by living plants in a geotechnical centrifuge. Ecol. Eng. 2017, 109, 207-227. [CrossRef]

31. Operstein, V.; Frydman, S. The influence of vegetation on soil strength. Proc. Inst. Civil Eng. Ground Improv. 2000, 4, 81-89. [CrossRef]

32. Bischetti, G.B.; Chiaradia, E.A.; Epis, T.; Morlotti, E. Root cohesion of forest species in the Italian Alps. Plant Soil 2009, 324, 71-89. [CrossRef]

33. Hales, T.C.; Ford, C.R.; Hwang, T.; Vose, J.M.; Band, L.E. Topographic and ecologic controls on root reinforcement. J. Geophys. Res. Earth Surf. 2009, 114. [CrossRef]

34. Mao, Z.; Saint-André, L.; Genet, M.; Mine, F.X.; Jourdan, C.; Rey, H.; Courbaud, B.; Stokes, A. Engineering ecological protection against landslides in diverse mountain forests: Choosing cohesion models. Ecol. Eng. 2012, 45, 55-69. [CrossRef]

35. Adhikari, A.R.; Gautam, M.R.; Yu, Z.; Imada, S.; Acharya, K. Estimation of root cohesion for desert shrub species in the Lower Colorado riparian ecosystem and its potential for streambank stabilization. Ecol. Eng. 2013, 51, 33-44. [CrossRef]

36. Lee, I.M.; Sung, S.K.; Im, C.M. An experimental study on the effect of vegetation roots on slope stability of hillside slopes. J. Korean Geotech. Soc. 1991, 7, 51-66.

37. Gray, D.H.; Sotir, R.B. Biotechnical and Soil Bioengineering Slope Stabilization: A Practical Guide for Erosion Control; Wiley \& Sons: New York, NY, USA, 1996.

38. Zhang, L.; Xia, Z.; Zhou, Z.; Liu, D.; Xu, W.; Li, M.; Li, T.; Zhao, B. Experimental study on tensile properties and reinforcement ability of plant roots. Environ. Pollut. Technol. 2018, 17, 729-738.

39. Shin, E.C.; Lee, H.J.; Oh, Y.I. Prediction of Soil-water Characteristic Curve and Unsaturated Permeability Coefficient of Reclaimed Ground. J. Korean Geotech. Soc. 2004, 20, 109-120.

40. Fredlund, D.G.; Xing, A. Equations for the Soil-water Characteristic Curve. Can. Geotech. J. 1994, 31, 521-532. [CrossRef] 